\title{
Specify Type of Testing and Results if Yes
}

National Cancer Institute

\section{Source}

National Cancer Institute. Specify Type of Testing and Results if Yes. NCI Thesaurus.

Code C157105.

A directive to specify the type and results if the response is yes. 